EESTI NSV TEADUSTE AKADEEMIA TOIMETISED, 31. KOIDE

FOOSIKA * MATEMAATIKA, 1982, NR. 3

ИЗВЕСТИЯ АКАДЕМИИ НАУК ЭСТОНСКОН ССР. ТОМ 31 ФИЗИКА * МАТЕМАТИКА, 1982, № 3

T. KÄNDLER, P. KASK, P. PIKSARV,

A. SIRK, E. LIPPMAA

\title{
CHEMICAL KINETIC STUDIES BY FLUORESCENCE CORRELATION SPECTROSCOPY
}

\section{Synopsis}

In this paper the possibilities of low-noise fluorescence correlation spectroscopy in submillisecond kinetic studies are demonstrated. Because of the small relative signal amplitude (about $0.1 \%$ in our experiments), microscope optics to collect the fluorescence photons, photon counting and an effective data processing hardware clip-correlator were used. As photobleaching is a serious limiting factor in the fluorescence correlation experiment, a series of dyes have been tested for suitability in kinetic studies. As an example, the binding of Pyronine G and Cresyl Violet to rat liver DNA, its sonicated fractions and to Polyadenylic acid has been studied.

\section{Introduction}

Fluorescence correlation (FC) spectroscopy is a relatively new method for studying kinetic processes in solution [ ${ }^{1}$ ]. In this experiment a small sample volume is continuously exposed to an exciting light beam with constant intensity. The fluorescence intensity fluctuations caused by the stochastic fluctuations of the number of observable fluorescent molecules inside the sample volume, are under observation. The calculated fluorescence intensity autocorrelation function is a direct expression of the kinetics of the various processes that cause the molecular number fluctuations. In the perturbation techniques a similar function is called relaxation curve, but in the FC experiment this curve is determined continuously, without the use of a macroscopic relaxation process.

There are several different processes which can cause stochastic number fluctuations of the fluorescent molecules inside the sample volume, e. g. the flow of the solution through the sample cell, translational and rotational diffusion of dye molecules or molecular complexes, chemical reactions of the dye molecules with molecules of another species, intramolecular reactions of dyes or labelled molecules, including conformational changes and physical relaxation processes of the molecular excited states.

FC spectroscopy is widely used to study translational diffusion $\left[{ }^{2-6}\right]$ : Although there is a great interest to use this method in studying the kinetics of chemical reactions $\left[{ }^{1,7,8}\right]$, not much experimental work has been done $\left[{ }^{2}\right]$. Difficulties arise because of the high requirements to electronic and optical parts of experimental apparatus as well as to the materials under study.

The software correlation processing has been usual in FC spectroscopy; in studying. microsecond processes, we used the hardware clipcorrelator, for which we do not see reasonable alternatives. As for optics, we have chosen a design with relatively low requiremerits to the quality 
of optical components, so the blank (background) fluorescence is not a serious problem. We have also established the importance of the choice of dye for performing the successful FC experiment.

In the following we shall describe our FC spectrometer, present the criteria for the choice of dyes as well as discuss the results of the experiments on binding kinetics in dye-nucleic acid systems.

\section{Experimental}

As in the FC spectroscopy the signal amplitude is very small (in the experiments described below, about $0.1 \%$ ), therefore a relatively low signal-to-noise ratio turns out to be the most serious shortcoming. It causes rather strict demands on the design of the FC experiment on chemical reactions. These requirements can be fulfilled by the use of effective collecting optics, the use of an effective data processing correlator, and the choice of suitable stable dyes.

Optics. The optical part of our FC spectrometer is shown in Fig. 1 and is an improvement over our preceding equipment described in $\left[{ }^{5}\right]$. As the signal-to-noise ratio is proportional to the integral photon detection efficiency in FC experiments $\left[{ }^{9}\right]$, the aperture of optics, collecting the fluorescence, must be as large as possible. It may seem that the nearly $4 \pi$ sterrad collection mirror optics $\left[{ }^{2,4-6}\right]$ is the best. However, here the background fluorescence introduces very strict requirements on the cell window material and its polishing quality $\left[{ }^{2,5}\right]$. Microscope optics has been used in FC spectroscopy, too $\left.{ }^{3}\right]$. It allows one to collect on the photodetector up to about $30 \%$ of the whole emission (about $10 \%$ in our experiment, as a comfortable dry objective lens with aperture number 0.95 was used). At the same time effective diaphragming provides a means to get rid of the background fluorescence.

In our experiment (Fig. 1) the beam from an argon ion laser, operating in the TEM $M_{00}$ mode, is stabilized with the help of an electron-optical Pockels cell driven by the amplified photodiode current in a negative feedback circuit. T:a stabilizer operates from 0 to $20 \mathrm{kHz}$ and reduces the peak-to-peak value of the most prominent fluctuations of laser intensity occurring at 50,100 and $300 \mathrm{~Hz}$ to $\leqslant 0,2 \%$.

After passing a neutral density filter ATT, the beam is focused through a long focus lens $L 1$, flat mirror $M$ and a short focus achromatic lens $L 2$ on the sample cell. The thickness of the solution layer inside the cell is $2 \mathrm{~mm}$. The beam diameter at the focal spot is typically about $3 \mu \mathrm{m}$. The length under observation is about $10 \mu \mathrm{m}$, depending on the size of the aperture $A$, so the sample volume is about $10^{-10} \mathrm{ml}$. At the dye concentration $10^{-8} \mathrm{M}$, we observe the fluorescence of about $10^{3}$ molecules at the same time.

The fluorescence emission collection axis is nearly at right angles relative to the exciting beam. To cut off the scattered laser light, a glass filter $F$ is used. The fluorescence photons are counted by the photomultiplier PM1 (type ФЭУ-84-2 with a trialkali cathode). At short channel widths $(T<25 \mu \mathrm{s})$ distortions of autocorrelation functions caused by

Fig. 1. Schematic of the optical part of the FC spectrometer. MOD, Pockels modulator: $B S$, beam splitters; $P$. photodiode and amplifier; ATT, attenuator; $L 1, L 2$, lenses; $C$, cell; $M I C$, microscope; $F$, filter; $A$, aperture; $P M 1, P M 2$, photomultipliers.

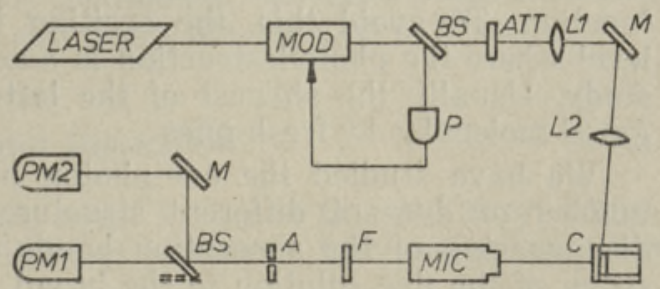


the relaxation phenomena inside the photon counter, particularly by afterpulsing of the photomultiplier, were noticed $\left[{ }^{10}\right]$. Two multipliers $P M 1$ and PM2 were used in such a case. The photomultipliers observe the fluorescence emission from the same sample volume and a crosscorrelation function between the sequences of pulses is computed. After the aperture $A$ the fluorescence light is a paraxial beam which allows one to use multiple internal reflection in the cathode windows of $P M 1$ and PM2 to enlarge the quantum efficiency of photodetection.

Electronics. The photon pulses from the photomultipliers are standardized with the help of a $40 \mathrm{MHz}$ amplifier-discriminator. The autocorrelation or cross-correlation function of the sequences of pulses of 10 ns width are calculated on a 32-channel clip-correlator, which is described at length in $\left[^{11}\right]$. This asvnchronous on-line correlator makes it possible to obtain correlation functions with correlation times from $1 \mu \mathrm{s}$ to $10 \mathrm{~s}$ (channel widths from $100 \mathrm{~ns}$ to $0.84 \mathrm{~s}$ ). We have found noticeable distortions at short channel widths, produced by the influence of occasional electric pulses in the ground wires on the action rate of clock pulses in asynchronously working units. This phenomenon is unpleasant to locate and check. Distortions are of about $0.002 \%$ at the channel width of $400 \mathrm{~ns}$, for example. The distortions are practically unnoticeable at longer sampling times, particularly in the experiments described below.

Correlation function is read out of the correlator and transferred into the computer memory by a data exchange kit based on the INTEL 8085 microprocessor. The correlation functions measured at different time scales (channel widths) are sewn together by the linear least-square method and plotted in logarithmic time scale. The curve fitting is performed by the linearized least-square method similar to that used in the case of exponential terms only $\left[{ }^{12}\right]$.

Materia1s. The dyes Pyronine G and Cresyl Violet were from Fluka, Lissamine-Rhodamine B200 from Schuchardt \& Co, and were used without purification. K salt of Polvadenylic acid $\left(S_{m}=4.6-5.0\right)$ was from Reanal. Rat liver DNA (Mol. wt. 30-40 MDaltons) was a gift from Dr. M. Saarma.

The solutions of rat liver DNA-Pyronine $\mathrm{G}$ were made in buffer $10 \mathrm{mM}$ tris- $\mathrm{HCl}, 50 \mathrm{mM} \mathrm{NH}{ }_{4} \mathrm{Cl}, 50 \mathrm{mM} \mathrm{KCl}, 10 \mathrm{mM} \mathrm{Mg}\left(\mathrm{CH}_{3} \mathrm{COO}\right)_{2}$, $3 \mathrm{mM} \beta$-mercaptoethanol, $\mathrm{pH}=7$. The other solutions were made in $20 \mathrm{mM}$ tris $-\mathrm{HCl}$ buffer, $\mathrm{pH}=7.5$ with $0.1 . \mathrm{M} \mathrm{NaCl}$.

The choice of dyes. At ordinary conditions in a FC experiment the signal-to-noise ratio is proportional to the mean intensity of fluorescence per dye molecule inside the sample volume $\left[{ }^{9}\right]$. Naturally, there are limits to increasing the exciting light intensity. The most limiting factor which strictly narrows the possibilities of the FC experiment, turns out to be the photochemical destruction of dye molecules $\left[{ }^{3}\right]$. Destroying the dye molecules whose behaviour is under study and producing unwanted substances which can influence the behaviour of the whole sample, the photochemical processes cause distortions of the measured correlation function. To avoid this, the exciting light intensity must be held at a level where the photodestruction is much slower than the processes under study. Usually the slowest of the latter is the exchange of the investigated molecules by fresh ones.

We have studied the one-photon photobleaching characteristics of a number of dyes of different structure. We have observed the rate of disappearing of the absorption bands of the dye, produced by the exposition of the dye solution to the broad laser beam. In air-saturated water 
Fig. 2. The correlation functions for a $2 \times 10^{-9} M$ Lissamine-Rhodamine B200 in water at 4 (3), 30 (2), $60 \mathrm{~mW}$ (1) excitation.

solutions the quantum yield of photobleaching (i.e., the number of molecules destroyed per photon absorbed) is of the order of $10^{-7}$ $10^{-6}$ for rhodamines and pyronines, increases to $10^{-5}-10^{-4}$ for Ethidium Bromide, fluoresceins, safranins and thionins, to $10^{-4}-10^{-3}$ for acridine dyes and to as high

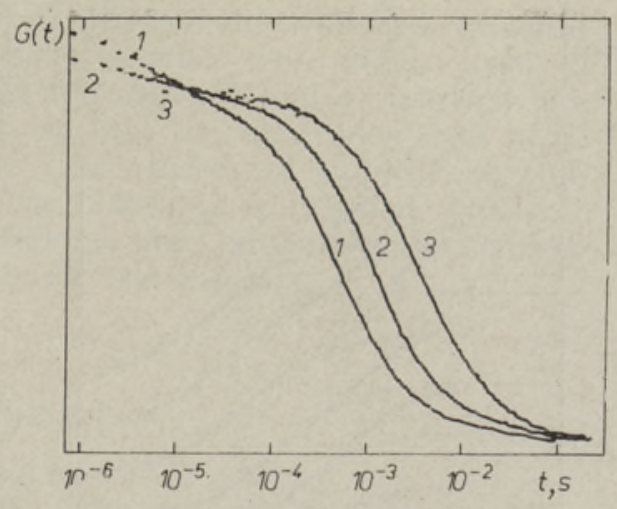
as $2 \times 10^{-3}$ for riboflavine, for example. The practical level of quantum yield of photobleaching for an FC experiment with a satisfactory signalto-noise ratio is about $10^{-5}$. Most of the fluorescent substances simply turn out to be unsuitable for FC spectroscopy.

The results of our FC experiments on different dye solutions show that the one-photon photodecomposition is not the only process producing intensity-dependent distortions of the measured correlation function. The effect of high excitation intensity is not only a slightly more rapid decay of the single translational diffusion term, but also an appearance of fast extra terms. As an example, Fig. 2 represents the measured correlation functions for a " $2 \times 10^{-9}$ molar Lissamine-Rhodamine B200 solution in water under $4 \mathrm{~mW}, 30 \mathrm{~mW}$ and $60 \mathrm{~mW}$ of $514.5 \mathrm{~nm}$ laser excitation. (At the $60 \mathrm{~mW}$ irradiation, the excitation rate of a dye molecule inside the beam is calculated to be about $10^{-7} \mathrm{~s}^{-1}$.) The fast terms can be described as a sum of two exponential functions with decay times of $2.3 \pm 0.2 \mu \mathrm{s}$ and $11 \pm 2 \mu \mathrm{s}$. Their amplitude is proportional to the excitation intensity while the decay time does not significantly depend either on intensity or on the dye concentration. Similar terms have been observed for a number of rhodamines and pyronines. Most probably, these terms are caused by reversible trapping of dye molecules into «nonactive» excited states for time intervals of a few microseconds. These extra terms may turn out to be disturbing in FC experiments on the chemical kinetics of binding. The experiments described below have been carried out at lower laser intensities, where the measured correlation curve does not depend on the excitation intensity.

To study the binding of a dye to a molecule of another species, the intensity of fluorescence emission of a dye in the free and in the bound state has to be different. In some special cases, as for Ethidium Bromide, the quantum yield of fluorescence increases in a complex with polynucleic acid. For the most part of dyes, the absorption curve shifts, normally to longer wavelengths, for the bound dye. We have chosen two dyes, Pyronine G and Cresyl Violet, for our studies. These have the quantum yield of photobleaching about $5 \times 10^{-7}$ and form complexes with polynucleic acid molecules. In the bound state these dyes show about twofold decrease in the extinction coefficients at the excitation wavelengths $501.7 \mathrm{~nm}$ for Pyronine $\mathrm{G}$ and $514.5 \mathrm{~nm}$ for Cresyl Violet.

\section{Results and Discussion}

The reversible binding of two basic dyes, Pyronine G and Cresyl Violet, to Polyadenylic acid, rat liver DNA and sonicated fractions of rat liver DNA, were studied. 


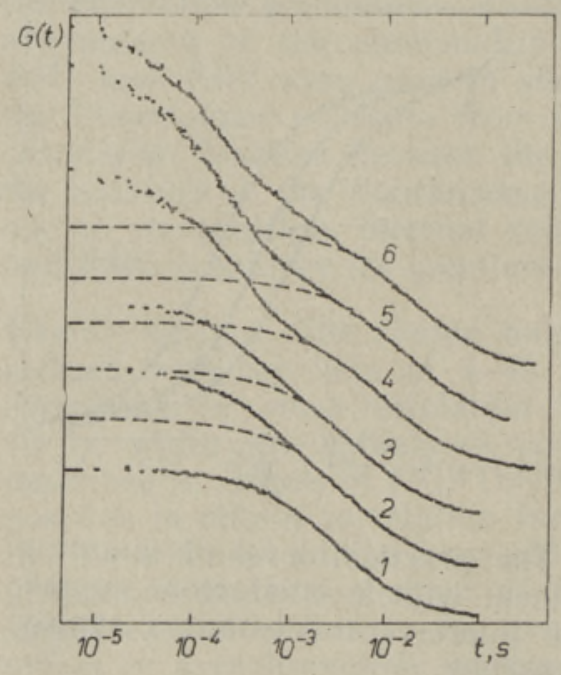

Fig. 3. A series of correlation functions for Pyronine $\mathrm{G}-\mathrm{DNA}$ at various DNA concentrations: 0 (1), 50 (2), 100 (3), 150 (5), $400 \mu \mathrm{g} / \mathrm{ml}$ (6). Concentration of Pyronine G was $4 \times 10^{-6} \mathrm{M}$. The dashed lines represent diffusion terms; for clarity the curves at various DNA concentrations have equally shifited abscissa axis.

It is reasonable to consider the correlation function to consist of different terms, or modes, as it is described in $\left[{ }^{2}\right]$. Each term corresponds to a certain kind of motion which causes the molecular number fluctuations.

In our experiments the intensity of fluorescence decreases when a dye molecule is in a complex with the polynucleic acid, basically because the absorption band of the complexed dye shifts to longer wavelengths. This way, the situation is slightly different from the case of Ethidium Bromide-DNA complex, described by Magde, Elson and Webb $\left[{ }^{2}\right]$. Neverti:cless, the slowest term in the correlation function describing the diffusion of polynucleic acid is practically absent in either case. If only the simple one-step binding-releasing reaction takes place, one could obtain two modes, the diffusion term with a time dependence of the type $1 /\left(1-1-t / \tau_{D}\right)$, where $\tau_{D}$ is the characteristic time of the diffusion of dye in the polynucleic acid solution into and out of the volume under observation, and the reaction term, which is practically exponential if the reaction is faster than diffusion, with the characteristic time depending on concentrations of reactants [ $\left.{ }^{1}\right]$.

In practice, however, the situation is more complicated. Similar to the Ethidium Bromide-DNA system $\left[{ }^{2}\right]$, in the systems under study there exist more than one reaction term in the correlation function in each case under discussion. The characteristic times of some of the reaction terms do not depend on the concentration of reactants. On the other hand, the amplitude of the reaction term increases with increasing the concentration of DNA, as expected.

As an example, in Fig. 3 a series of measured correlation functions for the mixture of Pyronine G and rat liver DNA is presented. (In this experiment the electric vector of exciting light was almost parallel to the direction of the detection of fluorescence, so the processes inside the complex should be maximally depressed.) Two terms, diffusion-like and exponential, are clearly insufficient to fit the curves. Three-term fitting gives reasonable concentration dependence of the characteristic time of the slowest component, the diffusion term only. Such dependence makes it possible to estimate the chemical equilibrium constants $K$ for the systems under study. For the dye-DNA system we found $K^{-1}=60 \pm 10 \mu \mathrm{g} / \mathrm{ml}$ without difference for Pyronine G or Cresyl Violet or for various sonicated fractions of DNA (down to mol. wt. 50000 daltons); for Pyronine G-Polyadenylic acid $K^{-1}=700 \pm 100 \mu \mathrm{g} / \mathrm{ml}$.

Alongside of the applications of FC spectroscopy to the dye-polynucleic acid systems, there exist many possibilities to extend the domain of FC experiments.

In addition to the second order (intermolecular) chemical reactions (dye-polynucleic acid, enzyme-fluorescent substrate and analogous systems), the study of first order (intramolecular) chemical reactions, 
for example conformational changes of fluorescent-labelled biomolecules, is possible. Translational diffusion studies are widely used in investigations of lateral transport in membranes $\left[{ }^{3}\right]$ and of labelled biomolecules $\left[{ }^{4}\right]$. If the binding is strong, so that the experiment has to be carried out at low concentrations, then the studies of equilibrium constants can be feasible, if only one of the reactants is labelled. The synthesis of new fluorescent substrate analogs may widen the up to now rather small group of dyes, applicable in FC spectroscopy.

\section{REFERENCES}

1. E I s o n, 'E. L., M a g d e, D., Biopolymers, 13, № 1, 1-27 (1974).

2. M a g d e, D., E1 s o n, E. L., W e b b, W. W., Biopolymers, 13, № 1, 29-61 (1974).

3. Koppel, D. E., Axelrod, D., Schles inger, J., El son, E. L., Webb, W. W., Biophys. J., 16, № 12, 1315-1329 (1976).

4. Rigler, R., Grasselli, P., Ehrenberg, M., Phys. Scr., 19, 486-490 (1979).

5. Kask, P., Kändler, T., S i rk, A., Ka ru, T., L i p pma a, E., ENSV TA Toim., Füüs. Matem., 28, № 3, 221-226 (1979).

6. Sorsher, S. M., Kle in, M. P., Rev. Sci. Instrum., 51, 98-102 (1980).

7. A r a gon, S. R., P e cora, R., J. Chem. Phys., 64, № 4, 1791-1803 (1976).

8. M a g d e, D., Quart. Rev. Biophys., 9, № 1, 35-48 (1976).

9. Ko p p el, D. E., Phys. Rev., A10, 1938-1945 (1974).

10. Gethner, J. S., F1 yn n, G. W., Rev. Sci. Instrum., 46, № 5, 586-591 (1975).

11. Sirk, A., Kask, P., Kändler, T., Karu, T., Puskar, J., Lippmaa, E., ENSV TA Toim., Füüs. Matem., 28, № 3, 227-232 (1979).

12. H i g b i e, J., Nucl. Instrum. Meth., 105, № 3, 279-282 (1972).

Academy of Sciences of the Estonian SSR,

Institute of Chemical Physics and Biophysics

Received

Dec. 16,1981

T. KANDLER, P. KASK, P. PIKSARV,

A. SIRK, E. LIPPMAA

\section{KEEMILISE KINEETIKA UURIMINE FLUORESTSENTS-KORRELATSIOONSPEKTROSKOOPIA ABIL}

Artikkel käsitleb madala müratasemega fluorestsents-korrelatsioonspektroskoopia rakendamise vōimalusi kineetilisteks uuringuteks submillisekundpiirkonnas. Signaali väikese suhtelise amplituudi tôttu (umbes $0,1 \%$ ) kasutati kirjeldatud eksperimendis fluorestsentsfootonite kogumiseks mikroskoopi, fluorestsentskiirguse registreerimiseks footonite loendajat ja andmete töötlemiseks klippkorrelaatorit. Katsetati rühma värvainete sobilikkust kineetilisteks uuringuteks. Uuriti püroniin G ja kresüülvioleti sidumist roti maksa DNH, selle fraktsioonide ja polüadenüülhappega.

Т. КЯНДЛЕР, П. КАСК, П. ПИКСАРВ,

А. СНРК, Э. ЛИППМАА

\section{ИССЛЕДОВАНИЕ ХИМИЧЕСКОЙ КИНЕТИКИ С ПОМОЩЬЮ КОРРЕЛЯЦИОННОЙ ФЛУОРЕСЦЕНТНОИ СПЕКТРОСКОПИИ}

Демонстрируются возможности корреляционной флуоресцентной спектроскопии малого шума в субмиллисекундных кинетических исследованиях. Из-за малой амплитуды относительного сигнала (около $0,1 \%$ в наших экспернментах) использованы микроскоп для собирания флуоресцентных фотонов, счетчик фотонов для регистрации флуоресцентной эмиссии и эффективный аппаратурный коррелятор с привязкой в одном канале для обработки данных. Испытана группа красителей в отношении их применимости для кинетических исследований. Исследована кинетика связывания пиронина Ж и крезилового фиолетового с ДНК печени крысы, ее фракциями и полиаденилозой кислотой. 